\title{
Feasibility of New Superior Varieties in Sub-optimal Dry Land in Sarmi Regency, Papua
}

\author{
Petrus A Beding (Corresponding Author) \\ Researcher at the Papua Agriculture Teknologi Study Center \\ Street Yahim Sentani no.49 Sentani Jayapura 99352, Indonesia \\ E-mail: peter.beding@gmail.com
}

Fransiskus Palobo

Researcher at the Papua Agriculture Teknologi Study Center

Yahim Sentani no.49 Sentani Jayapura 99352, Indonesia

E-mail: frans.merauke@gmail.com

\begin{abstract}
Batseba M. W. Tiro
Associate expert researcher at the Papua Agriculture Teknologi Study Center

Yahim Sentani no.49 Sentani Jayapura 99352, Indonesia

E-mail: batsebatiro68@gmail.com

Merlin K Rumbarar

Researcher at the Papua Agriculture Teknologi Study Center

Yahim Sentani no.49 Sentani Jayapura 99352, Indonesia

E-mail: merlinkornelia@pertanian.com
\end{abstract}

Received: Sep. 1, 2019

doi:10.5296/jas.v8i1.15382
Accepted: Nov. 3, 2019 Published: Dec. 8, 2019

URL: https://doi.org/10.5296/jas.v8i1.15382 


\section{Abstract}

Analysis of soybean farming on dry land through the Integrated Crop Management (ICM) approach has been carried out by the team in Tetom Village, Bonggo District, Sarmi Regency. This study aims to analyze the feasibility of soybean farming and the benefits of applying ICM technology with a Dem-farm approach of 6 ha, compared to the way farmers around. The study conducted from May to September 2015. The method used is on-farm research. To find out the feasibility of soybean farming using the $\mathrm{R} / \mathrm{C}$ ratio, $\mathrm{B} / \mathrm{C}$ ratio, the result showed that the Dering 1 variety gave the highest yield of $2.52 \mathrm{t} / \mathrm{ha}$, Anjasmoro $1.18 \mathrm{t} / \mathrm{ha}$, Kaba $1.03 \mathrm{t} / \mathrm{ha}$, Galunggung $0.90 \mathrm{t} / \mathrm{ha}$, and the finest varieties are Burangrang $0.61 \mathrm{t} / \mathrm{ha}$ and Tanggamus $0.60 \mathrm{t} / \mathrm{ha}$. Based on the results of financial analysis, the introduction of soybean varieties can benefit farmers; namely, the Dering 1 variety has a very high profit of Rp. 8,995,000 with R /C 2.29 and B/C 1.92, while the lowest profit is Rp. 715,000 with R/C 1.15 and $\mathrm{B} / \mathrm{C} 0.15$. Thus illustrating that the Dering 1 and Anjasmoro varieties provide higher returns than other varieties and are financially feasible to develop.

Keywords: soybean, financial feasibility, ICM, farmer's income

\section{Introduction}

Agricultural development is one of the keys to a sustainable economy and also has a strategic role in rural development. The focus of long-term economic growth with the primary goal of achieving a balance between agriculture and industry. For this reason, the strength and capability of the agricultural sector needed so that a reliable and advanced industrial sector (Syahza, 2001).

The agricultural sector, which has a strategic and essential role, is the food crop sector. The food crop sector is a producer of essential food ingredients. For the population of Indonesia, so that other areas except food imports cannot adequately substantiate this role. Food crops are plants that are cultivated to meet human needs for carbohydrates, fats, and proteins derived from plant foods. Food crops include rice, cereal maize, sweet potatoes, and beans such as soybeans, green beans, peanuts, cowpea, and koro beans (Meryani, 2008).

One of the primary food commodities that gets the main priority to developed is soybean (Balitbangtan, 2005). The need for soybean commodities continues to increase from year to year both as a leading food ingredient, animal feed, and as a large-scale industrial raw material (manufacturer) to small scale (household) (Kementan, 2012).

Soybean production in Indonesia is relatively low and even cannot meet consumer needs, which tend to increase. Multiple reasons such as inferior farming technology, lacking skill and readiness of farmers, availability of production facilities, lack of continuities to carry out the production to marketing level caused low soybean production.

In total, Soybean production in Papua in 2017 only reached 2,286 tons, while soybean production in Sarmi Regency has now reached 1035 tons with its productivity level 1.1 tons/ha and harvest area of 837 ha (BPS Papua, 2010). Based on these statistics, efforts need to be made to increase soybean production in Sarmi District, besides planning on expanding 
the planting area, which is necessary to make improvements in the pattern of soybean cultivation. In Papua, Sarmi Regency is one of the centers for soybeans, which has the potential for the development of soybean cultivation.

In the present time, soybean productivity at farmer reaches $1.4 \mathrm{t} /$ ha with a range of 0.6-2.2 $\mathrm{t}$ / ha, while based on research by applying site-specific cultivation technology ranging from 1.7-3.2 $\mathrm{t} / \mathrm{ha}$, depending on the conditions of the land and the technological components applied (Balitbangtan 2015). The low yield at the farmer mostly because of lack of attention in the use of superior varieties, simplicity of cultivation techniques, relatively low soil fertility, disturbance of weeds and pests, and inadequate postharvest handling (Malik 2008). Therefore, applying site-specific cultivation technology is necessary for addition to other technological cultivation. In terms of extensification, various efforts have been made to expand land for soybean plantations, including sub-optimal land, facing unfavorable conditions (Kementan, 2014). Sub-optimal land use is also still being challenged even though it is likely to be examined from unmanaged areas (Haryono, 2013).

Opportunities for increasing soybean production in the country are still wide open, both through increasing productivity and expanding planting areas. The expansion of the soybean planting area is one of the effective ways to increase national soybean production, given the enormous potential of available land. Papua has the potential area for agricultural expansion practices, and soybeans are one of the food crop commodities that has prospects to be developed in this easternmost province in Indonesia.

Further to extensification, another way to increase soybeans is intensification through Integrated Crop Management (ICM), which combines five essential technological components and five additional components of mixed technology (Marwoto et al., 2009). Some results of the study show soybean productivity with better ICM application. Compared to the way farmers (Tamburianetal., 2010) Sipahutar et al., Nugrahaeni et al. 2013)

In order to speed up the process of adopting ICM technology, a mass technological breakthrough through the application of technology in a focused, systematic, synergistic and integrated manner both in terms of guidance and financing, namely by implementing Integrated Crop and Resource Management (ICM). If with good farming, each farmer must be able to combine the production unit into one farm as a whole. Thus, the farmer can calculate the costs in his farming. Income is the main target that drives development in farming activities (Mubyarto, 1989). Soekattawai (2006) states that farming is one of the sciences that studies show one person allocates available resources efficiently and effectively to gain advantages over the input. Whereas Sulastri et al. (2011) stated, farming is a production organization, farmers as executors to organize land, labor, and capital, which are designated for production in agricultural fields either base on profit-seeking or not. Farming is said to be successful if farming is closely related to income and costs incurred.

Analysis of farming includes analysis of income, business services financially, and studying the effect of labor costs and income. According to Soekartawi 2002, farming income is all income received by people in farming economic activities in a certain period. The research aims to analyze the feasibility of soybean farming and the benefits obtained if the application of ICM technology. 


\section{Methodology}

The research was conducted in Tetom Village, Bonggo District, Sarmi Regency. The research location was chosen purposively by considering that the village was the area with the majority of soybean farming, so the income was obtained from farming results. This research was conducted in May - October 2015. Research activities using the On Fram Research (OFR) method.

\subsection{Method of Collecting Data}

The method used is a participatory understanding of the rural area. The discussion material is emphasized on the input of technological components applied by farmers in soybean cultivation. The discussion group is divided into two, namely cooperative farmers (applying introduction technology) consisting of 1 farmer group, which is membership of 15 farmers and farmer groups, which are members of 15 non-cooperating farmers (applying original technology). The discussion material is arranged in a guide that serves to direct the discussion to be on target.

The data collected is focused on the data used by production facilities: production costs, substantial costs, and the price of production of physical union. The method of data collection is carried out by periodic monitoring or recording. As supplementary data, secondary data is collected from the village, agricultural services, and information from local extension workers.

\section{Data Analysis}

Financial feasibility was tested for the application of ICM components with introduction packages and farmers' technological package patterns as presented in table 1.

In this study, financial feasibility was tested for the application of ICM components with introduction packages and farmers' technology package patterns as presented in table 1.

Table 1. ICM technological component (introduction and pattern of farmers)

\begin{tabular}{|c|c|c|c|}
\hline No & Description & Introduction pattern & Farmer Pattern \\
\hline 1 & Tillage & Perfect Land & Minimum tillage \\
\hline 2 & Seed & Labeled & Unlabeled \\
\hline 3 & Varieties & $\begin{array}{l}\text { Dering 1, Ajasmoro, Kaba, } \\
\text { Galunggung, Burangrang }\end{array}$ & Local \\
\hline 4 & Seed Quality & Certified (FS) & \multirow{2}{*}{$\begin{array}{l}\text { Production results from the } \\
\text { previous planting season } \\
\text { dibber }\end{array}$} \\
\hline 4 & $\begin{array}{l}\text { How to grow and cropping } \\
\text { systems }\end{array}$ & dibber & \\
\hline 5 & Number of seeds / holes & 1-2 seeds / hole & $2-3$ \\
\hline \multirow[t]{4}{*}{6} & Dose of fertilizer & & \multirow[t]{4}{*}{ Phonska $100 \mathrm{~kg}$} \\
\hline & Urea & $50 \mathrm{~kg} / \mathrm{ha}$ & \\
\hline & SP-36 & $100 \mathrm{~kg} / \mathrm{ha}$ & \\
\hline & $\mathrm{KCl}$ & $75 \mathrm{~kg} / \mathrm{ha}$ & \\
\hline 7 & Pest / disease control & IPM & Without reference \\
\hline 8 & Post-harvest & Use shift & manual \\
\hline
\end{tabular}




\section{Macrothink}

The balance of revenue and or R/C was analyzed to determine the value of farming from the two patterns (Surattyah, 2006). According to Soekartiwi (2002), farming is between the receipts (TR) and all costs (TC), where farming receipts are multiplications between production and selling prices, and costs are all expenditures used in farming. All of formula that used in the analysis are follow:

1. Analysis of income and profits

$\pi=\mathrm{TR}-\mathrm{TC}$

where : $\pi \quad=$ Income

$\mathrm{TR}=$ Farming receipts

$\mathrm{TC}=$ Farming expenses (total)

2. Analysis of the balance of revenue for costs

$\mathrm{R} / \mathrm{C}$ with the formula:

$\mathrm{R} / \mathrm{C}=$ Total revenue

Total cost

3. Analysis of the balance of revenue for costs

$\mathrm{B} / \mathrm{C}$ with the formula:

$\mathrm{B} / \mathrm{C}=\quad$ Total income

Total production costs

Farming valuation methods include:

$\mathrm{B} / \mathrm{C}$ ratio $>1$, then the farming should be continued, but if the $\mathrm{B} / \mathrm{C}$ ratiois $<1$, then the business is not feasible or loses. To compare the advantages of the technology applied through ICM and the technology applied by farmers, the analysis of Marginal Benefit-Cost Ratio (MBCR) was used with the following formula (Malianet.al. 1989):

MBCR $=$ Total gains

Total Losses

The transition of the application of technology to ICM technology is said to be superior if the value of MBCR> 2 (Adanyana and Kariyasa 2006).

Whereas to find out the farmer's response, discussion session was conducted with farmers for each application of technology. Of the five components applied in the application of PPT, the responses were asked by farmers, namely seed VUB, seed quality, plant spacing, fertilization, use of leaf color chart (BWD), which was used in rice and maize planting. Responses and perceptions were given a score of 1-5. The higher the score, the better the response. The scoring results are followed by Lingkert analysis (1932) with the following formula:

Score $=\mathrm{n} \times$ bn 
Where Score: score of at least one and a maximum of 5

$\mathrm{n}$ : Number of respondents who state a particular score

Bn: Score weight: 1 = disagree, $2=$ disagree, $3=$ somewhat agree, $4=$ agree, and $5=$ very agree

$\mathrm{N}$ : Number of total Respondents

\section{Results and Discussion}

\subsection{The Geographical Location of the Research Area}

Sarmi Regency is one of the Regencies in Papua, the easternmost Province of Indonesia. Geographically, it is located on the northern coast at $138^{\circ} 05^{\prime}-140^{\circ} 30^{\prime} \mathrm{E}$ and between $1^{\circ} 35^{\prime}$ - $3^{\circ} 35$ ' S with the following border: Sarmi Regency supports regional boundaries: North of the Pacific Ocean, south of Membramo Raya District, west of Tolikara, and east of Jayapura Regency. Sarmi Regency has an area of 13,965 Km2 divided into ten districts. Sarmi district is more than half of the Sarmi Regency (52.3\%) and rose as lowland with an altitude of $<100$ $\mathrm{m}$ above sea level. Other districts on the regency are West Coast, East Coast, Bonggo, Sarmi Timur, South Sarmi, and West Bonggo. All these remain district is located at an altitude between $100 \mathrm{~m}$ - $500 \mathrm{~m}$ above sea level.

\subsection{Performance of Existing Soybean Technology}

Results of the needs and chance study (KKP) showed that farmers had not applied soybean cultivation techniques properly. In general, farmers use seeds from their crops which are planted continuously, and some of them use labeled seeds. Most of the farmers work with their own seed basically because this it is highly preferred by traders; the selling price and yield are still high. Whilst some farmers to choose new superior varieties because it is cheaper in terms of production costs, higher production, high resistance to pests and diseases, early maturity, and easy maintenance.

One of the success factors in managing soybean farming is determined through the use of production inputs. The optimal use of production inputs will produce maximum production and ultimately provide relatively high farming benefits. Recommendations of the use of production inputs are already known by farmers, but in practice, not all farmers apply recommended inputs. Therefore, results in soybean productivity being different between farmers, location, and season and level of assessment.

\subsection{Performance of Introductory Technology and Farmer Patterns.}

Performance of Integrated crop management technology and farmers 'patterns showed that the average NSV sprouts growth capacity of $96.00 \%$ and $95 \%$, respectively. The average height at harvest shows that the Kaba variety has a very high level different from the other four varieties. While the harvest age of the five NS varieties shows the same general performance at harvest when compared with the local variety (Tanggamus) 85, 00\% is presented in Table 2. 
Table 2. Soybean agronomic performance in the application of ICM components and farmers' patterns on sub-optimal land in Tetom Village, Bonggo District, Kab. Sarmi, 2015

\begin{tabular}{llccc}
\hline No. & Varieties & Power grows (\%) & $\begin{array}{r}\text { Plant height at harvest } \\
(\mathrm{cm})\end{array}$ & Harvest Age (hari) \\
\hline 1 & Anjasmoro & 96,0 & 66,9 & 90,0 \\
2 & Dering 1 & 96,0 & 56,0 & 90,0 \\
3 & Kaba & 96,0 & 89,9 & 84,0 \\
4 & Burangrang & 96,00 & 73,1 & 80,0 \\
5. & Galunggung & 96,00 & 73,1 & 86,0 \\
6. & Variatas lokal & & 57,0 & 85,0 \\
& (Tanggamus ) & 95,00 & & \\
\hline
\end{tabular}

The observation of production parameters shows that there is no significant effect between treatments (varieties). The highest average number of crops achieved was obtained in the Kaba (65.43), then followed by Galunggung (49.47), while the lowest is obtained in local varieties (Tanggamus) (28.00). The highest number of empty pods was found in Anjasmoro (4.03). While the average production of the six varieties shows that the Dering 1 has the production $1.52 \mathrm{t} / \mathrm{ha}$, highest from all varieties and and the lowest production is showed on Burangrang and local variety which produces $0.61 \mathrm{t} / \mathrm{ha}$. The variety also influences the low production of soybean because each variety has advantages and disadvantages of each. The same thing is evident in the data analysis presented in Table 3.

Table 3. Soybean production parameters

\begin{tabular}{clccc}
\hline No. & Varieties & Number of pods per pithy & $\begin{array}{c}\text { Number of empty pods } \\
\text { per plant }\end{array}$ & $\begin{array}{c}\text { Production } \\
\text { (t/ha) }\end{array}$ \\
\hline 1 & Anjasmoro & 45,77 & 4,03 & 1,18 \\
2 & Dering 1 & 45,83 & 4,83 & 1,52 \\
3 & Kaba & 65,43 & 6,10 & 1.03 \\
4 & Galunggung & 49,47 & 4,56 & 0,90 \\
5 & Burangrang & 45,57 & 6,3 & 0,61 \\
6 & Varietas lokal & 28,00 & 4,66 & 0,61 \\
& (Tanggamus) & & & \\
\hline
\end{tabular}

Genetic, environment, and the interaction of genetic and environment are the main factors determined Soybean productivity. Improvement of environmental factors without the support of genetic factors will not succeed in increasing productivity, and vice-versa the use of high-quality genetic plant material will not be able to improve productivity without the support of environmental factors (Allard and Bradshaw, 1964). Environmental factors are referred to as the physical environment, the biological environment, and the socio-economic and cultural environment. Therefore, the selection of technology, including varieties, must consider the physical, biological, and socio-economic and cultural environment; besides that, productivity is influenced by varieties.

Variety is one aspect that needs to be considered in an effort to manage crop cultivation techniques. The selection of varieties plays an important role in the cultivation of soybeans, because to achieve a high level of productivity is largely determined by its genetic potential. If the management of the growing environment is not carried out well, then the potential for high yield of seeds from these superior varieties cannot be achieved (Adisarwanto, 2006). 
Lotti I. (2007) states that in general high yielding varieties have advantages compared to local varieties, both in terms of their growth characteristics and their production characteristics. Therefore, the use of high-quality varieties is the most basic and cheapest way among other ways to increase crop production. Furthermore, Gardner, et al. (1991) stated that internal factors in genetic control vary from one variety to another. So that a variety that is suitable for a particular condition may not be suitable for other agro-climate conditions. In addition, each variety also has a different response to external factors, such as agro-input given to plants. Each variety also has a different response to external factors, such as agro-input given to plants

\subsection{Farm Analysis}

Measuring the rate of return on the cost of soybean farming has been calculated based on the ratio of acceptance of the input costs used, while farm income is the difference between the yield value and production costs. The results of farming analysis show that farm acceptance from the six varieties is very diverse. The highest acceptance was obtained from the use of Ring varieties, which is Rp. 9,985,000 with R/C 3.7; while Burangrang and local varieties with respectively 3.685,000 R/C 1.49. All six varieties show R / C> 1; thus, all six varieties are worth the effort.

Soybean varieties do not affect the selling price of soybeans, meaning that any soybean varieties the selling price of soybeans remains the same. Soybean farming is more influenced by selling prices and production quantities. In the research conducted, the total production cost of each variety is the same because the treatment given is the same, as well as the selling price is the same. The difference in $\mathrm{R} / \mathrm{C}$ of each variety is due to the different products produced between varieties. The simple farming analysis of several soybean varieties is presented in Table 4.

Table 4. Farm Analysis of Some Soybean Varieties

\begin{tabular}{clcccccc}
\hline No. & \multicolumn{1}{c}{ Varieties } & $\begin{array}{c}\text { the results } \\
(\mathrm{kg} / \mathrm{ha})\end{array}$ & $\begin{array}{c}\text { Cost } \\
(\mathrm{Rp} / \mathrm{ha})\end{array}$ & $\begin{array}{c}\text { Reception } \\
(\mathrm{Rp} / \mathrm{ha})\end{array}$ & $\begin{array}{c}\text { Income } \\
(\mathrm{Rp} / \mathrm{ha})\end{array}$ & $\mathrm{R} / \mathrm{C}$ & $\mathrm{B} / \mathrm{C}$ \\
\hline 1. & Anjasmoro & 1,180 & 4.685 .000 & 10.620 .000 & 5.935 .000 & 2,27 & 1,27 \\
2. & Dering 1 & 1,520 & 4.685 .000 & 13.680 .000 & 8.995 .000 & 2,29 & 1,92 \\
3. & Kaba & 1.030 & 4.685 .000 & 9.270 .000 & 4.585 .000 & 1,98 & 0,98 \\
4. & Galunggung & 900 & 4.685 .000 & 8.100 .000 & 3.415 .000 & 1,73 & 0,73 \\
5. & Burangrang & 610 & 4.685 .000 & 5.490 .000 & 805.000 & 1,17 & 0,17 \\
6 & varietas & 600 & 4.685 .000 & 5.400 .000 & 715.000 & 1,15 & 0,15 \\
\hline
\end{tabular}

Actually, varieties do not affect the selling price of soybeans, meaning that for any varieties, the selling price of soybeans remains the same. Thus, soybean farming is more influenced by selling prices and production quantities. In the research conducted the total production cost of each variety is the same because the treatment given is the same, as well as the selling price is the same. The difference in $\mathrm{R} / \mathrm{C}$ of each variety is due to the different production produced between varieties. 


\subsection{Farmer Perception Rate}

The level of farmers 'preferences is seen based on the farmers' response to the ICM technology performance. Both before and after planting, many farmers are waiting for new superior soybeans to be replanted on their land, including farmers around the crop and those who have passed the crop. In the soybean farming business, the main problems they face are the availability of superior seeds and marketing. Farmers are basically ready to develop widely if the market guarantees. So to develop soybean, not only the aspects of cultivation that need to be addressed, but the marketing aspect that gives assurance to farmers that the business will be profitable and competitive with other crops (Rozi, 2013). Farmers' responses and assessment of soybean ICM components can be seen in table 5.

Table 5. Farmer's response to the application of soybean ICM components in Sarmi Regency, Papua, 2015

\begin{tabular}{lllllll}
\hline \multirow{2}{*}{$\begin{array}{l}\text { Technology } \\
\text { assessed }\end{array}$} & \multicolumn{7}{c}{ Respondents' responses and perceptions } & Score \\
\cline { 2 - 7 } & SSt & St & ASt & KSt & TSt & \\
\hline Superior varieties & 17 & 29 & 3 & 1 & 0 & 4,20 \\
High quality seeds & 11 & 39 & 1 & 2 & 0 & 4,36 \\
Spacing & 4 & 6 & 28 & 13 & 0 & 3,44 \\
Use of organic fertilizer & 2 & 14 & 20 & 24 & 0 & 2,92 \\
Phoska fertilizer as a source & 5 & 20 & 19 & 6 & 0 & 4,68 \\
of NPK & 5 & 10 & 25 & 10 & 0 & 3,80 \\
How to apply fertilizer & 5 & & & & & \\
\hline
\end{tabular}

SSt (strongly agree), St (agree), Ast (Somewhat agree), KSt (Less agree) and TSt (disagree)

Soybean superior varieties in demfarm with ICM technology are accepted, because they produce healthier plants with more roots, grow faster and more evenly and do not require replacing. In addition, using certified seeds that are clean and uniform can provide the lowest germination rate of 90 percent. All introduced varieties are all favored because of the very good appearance of plants, from the number of high pods, large seeds so that they can produce yields, optimal plant populations, high yields. The number of seeds / hole 2 grains will save the use of seeds. Fertilization must be given so that the plant is healthier and resistant to lodging. Fertilization methods carried out by farmers are still inefficient and ineffective because fertilizer is given near the planting hole without being covered with soil and uneven, so the impact of discoloration is less visible.

On the survey, approximately $90 \%$ of farmers preferred Dering, Kaba, and Ajasmoro varieties. Their preferential simply based on observations ranging from growth in the field to yield production. These three varieties have large seeds, and promising market prospects. New varieties that have the prospect of being developed into new superior seeds by the local farmers in Sarmi are Dering1 and Anjasmoro.

\section{Conclusion}

The soybean farming carried out in this activity possesses the highest feasibility level owned by the Ringing 1 variety compared to the other five varieties and deserves to be destroyed finely through an integrated crop management approach with an $\mathrm{R} / \mathrm{C}$ ratio of 2.29 and a 
value, B / C of 1.92 Besides that, farmers' perceptions or responses to the introduction of technology components which are considered to indicate that the use of high yielding varieties have the highest score followed by quality seeds, this has an impact on increasing the productivity of soybean itself.

\section{References}

Adisarwanto. (2006). Study of Some Superior Soybean Varietieson Dry Land. Study program.

Adnyana, M. O., \& Kariyasa, K. (2006). Impacts and perceptions of farmers on the application of integrated rice field management systems. Food Crop Research, 25(1), 2006

Agronomy, FacultyofAgriculture, Bogor Agricultural University. Bogor.

Allard, R. W. dan B. (1964). Implikasi of Genotype Enviromental Interction in Applied Plant Breeding. Crop Sci., 4, 503-508.

https://doi.org/10.2135/cropsci1964.0011183X000400050021x

Balitbangtan, (2005). Strategic Planning Agricultural Research and Development Agency

Balitbangtan. (2015). Increasing Soybean Production Supports Food Production and Self-Achievement Achievement. http://www.litbang.pertanian.go.id/info-aktual/2116/[Januari 20, 2015]

BPS Papua, (2011). Papua in Numbers 2010. Papua: BPS Papua

Gardner, F. P., Pearce, R. B., \& Mitchell, R. L. (1991). PhysiologyofCultivationPlants. UI-Press. Jakarta. 428 p.

Haryono, (2013). Meajamen Litkajibangdilatluhrap supports the study and dissemination of agricultural innovation programs. Meeting. BB2TP Work with the theme 'Consolidation of Litkajibangdiklatluhrap Management Arrangement Supports the completion of the 2014 Specific Agricultural Assessment Program" Kudus 20-23 March 2013.

Kementan, (2014). Remarks and Direction in the Workshop on the Coordination of Strengthening National Rice Production Enhancement (P2BN) in the framework of the MT.2013 / 2014 Evaluation and 2014 MT Strengthening Astria Serpong Hotel, 23-24 April 2014

Likert, R. (1932). A Technique for the Measurement of Attitudes. Archives of Psychology, 140, $1-55$.

Lotti, I. (2007). Influence of Varieties, Flow Control of Chicken Coop Fertilizer and Plant Layout on Soybean Growth and Production. Thesis. Postgraduate Agronomy Program, Bogor Agricultural University. Bogor.

Malian, A. H., Djauhari, A., \& Van Der Veen, M. G. (1989). Economic Analysis in Farming Systems Research. Training materials for Economic Analysis of Farming systems. Maros, 11 pornography - March 3, 1989.

Malik, A. (2008). The Comparativeandcompetitiveadvantageoffoodcrops in Papua production centers (case in Jayapura District). SEPA Agricultural and Agro-EconomicJournalof SEPA, 5, $1-9$. 
Marwoto, S. T, Sudaryono, A., Kasno, A., Hardaningsih, S., Setyorini, D., \& Adie, M. M. (2009). General Guidelines of Soybean ICM. Jakarta Agricultural Research Agency

Meryani, N. (2008). Analysisof Farming and Trading in Soybeandi Ciranjang District, Cianjur Regency, Cianjur.115 p

Ministry of Agriculture (2012), Soybean SL-ICM Technical Guidelines. Directorate of Beans and Tuber Cultivation. Directorate General of Food Crops.

Ministry of Agriculture, (2008). Guidelines for Implementation of Soybean Integrated Crop Management (SL-ICM) Field School. Agriculture Department.

Mubyarto. (1989). Introduction to Agricultural Economics. Institute for Economic and Social Education and Information Research (LP3ES). Jakarta.

Nurgraeni D., Sari, E., Jamil, A., \& Nurhayati, (2009). Performance of several new superior varieties of soybeans in Rokan Hilir Regency, Riau Province, Proceeding sof Balitkabi. Malang

Rozi, F. (2013). Changes in farmers' production behavior with the SL-ICM Program accelerate soybeanself-sufficiency. Proceeding sof the Balikabi National Seminar. Malang

Soekartawai. (2006). Farm Analysis. UI Press, Jakarta.

Soekarwati, (2002). Basic Principles of Agricultural Economics, Theories , and Applications. PT. King. Grafindo Prasada. Jakarta.

Sulastri, S., Yuliati, Y., \& Soemarno. (2011). Analysis of Sustainable Soybean (Glycinemax L) Farming in Sukorejo District, Ponorogo Regency. Graduate program. Brawijaya University, Malang

Suratiyah. (2006). Agricultural Sciences. Self-help Spreaders. Jakarta.

Swartika D. K. S. Principles of economic technical analysis in agricultural technology, 7(1) 90-103. Agricultural Social Economic Pulisbang.

Syahza, A. (2001). Researchers and Agribusiness Development in Karimun Regency. Sri Press, Pekanbaru.

Tabmburian, Y. W., \& Remabngand, B. (2010). Sustainable Soy-quality Superior Clear Production System Review to support the Strategic Program for Increasing Soybean Production in North Sulawesi. Paper presented at the National Seminar on BB2TP. Cisarua, December 17-19, 2010.

\section{Copyright Disclaimer}

Copyright for this article is retained by the author(s), with first publication rights granted to the journal.

This is an open-access article distributed under the terms and conditions of the Creative Commons Attribution license (http://creativecommons.org/licenses/by/4.0/). 